\title{
COMPUTER-AIDED DESIGN ELEMENTS OF PRECISION FARMING SYSTEMS BASED ON THE PRINCIPLES BIOLOGIZATION, RESOURCE AND ENVIRONMENTAL SAFETY
}

\author{
АВТОМАТИЗАЦИЯ ПРОЕКТИРОВАНИЯ ЭЛЕМЕНТОВ ПРЕЦИЗИОННЫХ СИСТЕМ \\ ЗЕМЛЕДЕЛИЯ НА ОСНОВЕ ПРИНЦИПОВ БИОЛОГИЗАЦИИ, РЕСУРСОСБЕРЕЖЕНИЯ И \\ ЭКОЛОГИЧЕСКОЙ БЕЗОПАСНОСТИ
}

V. Lobkov, Doctor of Agricultural Sciences

В.Т. Лобков, доктор сельскохозяйственных наук

S. Plygun, Candidate of Agricultural Sciences

С.А. Плыгун, кандидат сельскохозяйственных наук

Orel State Agrarian University, Orel City, Russia

Орловский государственный аграрный университет, г. Орёл, Россия Phone: +7 (4862) 45-40-37, E-mail: borpli@rambler.ru

Received January 10, 2012

\begin{abstract}
Development of practical methods of computer-aided design elements of precision farming systems on the basis of biological function, resource and environmental security for the producers of different specialization, ownership and financial security is the actual direction of development of modern agricultural science. Proposed development, which may serve as a basic programming model, allowing for expanded reproduction of soil fertility through the use of new ways to maximize the amount of phytomass in the agricultural lands, increase soil biological activity and reduce the costs of manufacturing nitrogen on yield formation of crops.

\section{АННОТАЦИЯ}

Разработка практических приемов автоматизированного проектирования элементов прециизионных систем земледелия на основе принципов биологизации, ресурсосбережения и экологической безопасности для товаропроизводителей различной специализации, форм собственности и финансового обеспечения является актуальным направлением развития современной земледельческой науки. Предложены разработки, которые могут выступать в качестве базовых программных моделей, позволяющих обеспечить расширенное воспроизводство плодородия за счет применения новых способов получения максимального количества фитомассы в агроценозах, повышения биологической активности почвы и уменьшения затрат технологического азота на формирование урожая сельскохозяйственных культур.
\end{abstract}

\section{KEY WORDS}

Automation; Agriculture system; Biologization; Ecological safety; Precision agriculture.

КЛЮЧЕВЫЕ СЛОВА

Автоматизация; Система земледелия; Биологизация; Ресурсосбережение; Экологическая безопасность; Преиизионное земледелие.

Обеспечение жизни на Земле - главная функция почвы. Почва как компонент биосферы участвует одновременно в процессах биогеоценотического, витасферного и биосферного структурных уровней её организации, занимая, таким образом, центральное положение во взаимодействиях геологического, микро- и макробиогеоценозного природных круговоротов. Почва упорядочивает все потоки веществ биосферы, регулируя также состав атмосферы и гидросферы. По сущест- 
ву, почва «замыкает» все биогеохимические циклы.

Значение почвы для хозяйственной деятельности человека определяется, в первую очередь, тем, что она является главным средством сельскохозяйственного производства и основой агроэкосистем. Человечество получает из почвы около 95\% всех продуктов питания. Именно поэтому забота о сохранении почвенного плодородия должна быть приоритетной не только в сельскохозяйственной, но и в других сферах деятельности, поскольку почва представляет собой к тому же незаменимое жизненное пространство, обеспечивающее обитание живых организмов. Как показывает практика, почва, будучи важнейшей жизнеобеспечивающей сферой, постоянно испытывает различные по времени, интенсивности, масштабам, последствиям воздействия, обусловленные многообразной производственной деятельностью человека. Антропогенное давление, проявляющееся, например, в развитии процессов эрозии и дигрессии, загрязнения и захламления, - явление глобального характера и вызывает серьёзную озабоченность мирового сообщества.

В Российской Федерации земли, используемые в различных хозяйственных целях, находятся в неудовлетворительном состоянии, что является следствием нерационального природопользования, в том числе и сельскохозяйственного, значительного сокращения работ по охране почв и земельных ресурсов, неэффективности существующих методов обеспечения соблюдения законодательства в сфере охраны и использования земель. Так, по данным В.А. Черникова за последнее десятилетие XX века в сфере сельскохозяйственного производства выпало из оборота порядка 20 млн. га пашни.

Сложность проблем в сфере охраны и обеспечения почвозащитного использования земель в значительной мере обусловлена тем, что для каждой проблемной ситуации необходимо вырабатывать и реализовывать адекватные решения, дифференцированные с учётом почвенных разностей и особенностей природных комплексов. С учётом состояния, в котором находится аграрный сектор экономики, и явно выраженных проявлений экологического неблагополучия, нельзя не увидеть, что сложившаяся ситуация угрожает необратимыми изменениями плодородия почв, ставя под серьёзное сомнение возможность обеспечения продовольственной безопасности государства.

Результаты интенсификации развития отрасли растениеводства на основе современных достижений научно-технического прогресса способствовали в значительной степени решению одной из важнейших проблем человечества - продовольственной. «Зеленая революция», сопровождавшаяся скачкообразным ростом продуктивности сельскохозяйственных культур, позволила, с одной стороны, достичь высокого уровня производства основных сельскохозяйственных культур, но, с другой, фактически способствовала превращению многих регионов мира в зоны экологического бедствия (Парахин, Лобков, 2006).

Мелиорация, химизация, использование средств механизации, низкая культура земледелия, пренебрежение основными экологическими принципами приводят к существенному усилению антропогенного воздействия на окружающую среду (Кирюшин, 2007).

Цель биологического земледелия - осуществлять сельскохозяйственное производство без нарушения экологического баланса в агроэкосистемах и агроценозах. Удовлетворение растений в факторах жизни в данном случае осуществляется посредством поддержания агрономически полезных естественных процессов в природе и их активизации. Исходя из этого, почва - основа жизни, высокая биологическая активность почвенной среды является условием поддержания ее способности обеспечивать растения земными факторами жизни.

В этой связи особую актуальность приобретает разработка экологически сбалансированных приемов и способов сельскохозяйственного производства, базирующихся в своем функционировании и развитии на принципы биологизации, ресурсосбережения и экологической безопасности.

В соответствии с планом проведения исследований по заданию II.01 «Разработать проекты базовых элементов адаптивноландшафтных систем земледелия (АЛСЗ) и модели автоматизированного проектирования для товаропроизводителей различной специализации, форм собственности и финансового обеспечения〉 Межведомственной координационной программы научных исследований Российской академии сельскохозяйственных 
наук на период до 2012 года, под руководством заслуженного деятеля науки Российской Федерации, доктора сельскохозяйственных наук, профессора В.Т. Лобкова на базе кафедры «Земледелие» ФГБОУ ВПО «Орловский государственный аграрный Университет» разработаны технологии, позволяющие сократить затраты антропогенных ресурсов на воспроизводство плодородия почв на $30-35 \%$ на основе использования автоматизированных программных комплексов для проектирования элементов прецизионных и адаптивноландшафтных систем земледелия.

Разработанные программные комплексы по проектированию элементов систем земледелия базируются на математических моделях, апробированных на широкой выборке землепользований хозяйствующих субъектов АПК Орловской области. При проектировании адаптивно-ландшафтных систем земледелия, в данном случае, расширенное воспроизводство плодородия обеспечивается за счет применения новых способов получения максимального количества фитомассы в агроценозах и приемов максимального вовлечения ее в биологический круговорот, позволяющих увеличить количество производимой фитомассы на 1 га на $35-40 \%$, а поступление свежего органического вещества в почву - на 40$45 \%$; повышения биологической активности почвы в 1,3-1,5 раза; уменьшения затрат технологического азота на формирование урожая сельско-хозяйственных культур в 1,4 раза.

Разработанные программные комплексы выполнены с использованием объектноориентированных сред программирования и предназначены для решения специализированных задач, стоящих перед сельхозтоваропроизводителями при планировании, организации и развитии производства сельскохозяйственной продукции.

Условно их можно разделить на три группы:

1. Программные разработки для планирования и организации производства сельскохозяйственной продукции - к данному классу относятся программы: «ietech 2.0 - составление и расчёт электронных технологических карт возделывания сельскохозяйственных культур», «agrochem 1.0 - расчёт норм удобрений в севообороте балансовым методом», «Моделирование структуры посевных площадей и севооборотов в природно- экономических условиях Центрального федерального округа (на примере Орловской области) v1.0», «Экономическая оценка эффективности технологии возделывания зерновых культур v1.0» и «Оценка эффективности использования производственного потенциала в сельском хозяйстве v1.0».

2. Программные разработки для оценки состояния почвенного комплекса и его влияния на уровень интенсификации производства: «FComparer v1.0 - расчёт агроэкологического потенциала и уровня почвоутомления в севооборотах сельскохозяйственных культур», «Почвенно-биологический фактор: сравнительная оценка биологической активности почвы v1.0», «Определение влияния степени эродированности почвы на урожайность полевых культур v1.0» и «Определение влияния факторов биологизации земледелия на баланс гумуса и питательных веществ в почве севооборота v1.0».

3. Программные разработки для оценки экологических рисков при планировании и размещении основных производственных мощностей: «RFilter v1.0 - расчёт скорости фильтрации загрязнителей почвенного и водоносных горизонтов в условиях сельскохозяйственного производства», «MFilter v1.0 расчет массопереноса в почвенном и водоносных горизонтах в условиях сельскохозяйственного производства», «Filter Complex v1.0 - расчет массопереноса в почвенном и водоносных горизонтах в вертикальном и латеральном направлениях в условиях интенсивного сельскохозяйственного производства» и «Агроэкологическая оценка удобрений: расчет содержания тяжелых металлов в традиционных и новых видах органических удобрениях v1.0».

В настоящее время для формирования высокоэффективных и экологически сбалансированных технологий производства сельскохозяйственной продукции, отвечающих всем требованиям современного производства, необходимо не только использование последних достижений научно-технического прогресса (технических разработок и решений, замкнутых технологических циклов), но и рациональное, ресурсосберегающее, эколого-ориентированное планирование хозяйственной деятельности.

Система земледелия - ключевой компонент к обеспечению эффективности агротех- 
нологий и сохранению национального достояния - почвы. Для обеспечения качественно нового уровня земледелия - прецизионного существует объективная возможность: с одной стороны, необходимые технические средства и ресурсы, с другой - современные программно-аналитические комплексы, способные автоматизировать планирование, организацию и развитие ключевых элементов системы земледелия.

Предлагаемые разработки являются базовыми программными моделями, которые позволяют обеспечивать расширенное воспроизводство плодородия за счет применения новых способов получения максимального количества фитомассы в агроценозах, повышения биологической активности почвы и уменьшения затрат технологического азота на формирование урожая сельско-хозяйственных культур. Достигается это благодаря учету комплекса ключевых элементов при планировании и организации производства сельскохозяйственной продукции, оценке состояния почвенного комплекса и его влиянии на уровень интенсификации производства, оценке экологических рисков при размещении основных производственных мощностей.

\section{БИБЛИОГРАФИЯ}

ietech 2.0 - составление и расчёт электронных технологических карт возделывания сельскохозяйствен-ных культур / В.Т. Лобков, Н.И. Абакумов, С.А. Плыгун // Свидетельство о государственной регистрации программы для ЭВМ №2006613438. - 2006.

agrochem 1.0 - расчёт норм удобрений в севообороте балансовым методом / В.Т. Лобков, Ю.А. Бобкова, С.А. Плыгун, Н.И. Абакумов // Свидетельство о государственной регистрации программы для ЭВМ №2007613639. 2007.

Генерация и восстановление данных в формате MD5 (base64) / B.T. Лобков, Ю.А. Бобкова, С.А. Плыгун, Н.И. Абакумов // Свидетельство о государственной регистрации программы для ЭВМ №2008612094. - 2008.

Agroweeds: каталог сорных растений Центральной России / В.Т. Лобков, Ю.А. Бобкова, С.А. Плыгун, Н.И. Абакумов // Свидетельство о государственной регистрации базы данных для ЭВМ №2008620016. -2008 .

FComparer v1.0 - расчёт агроэкологического потенциала и уровня почвоутомления в севооборотах сельскохозяйственных культур / В.Т. Лобков, С.А. Плыгун // Свидетельство о государственной регистрации программы для ЭВМ №2011614053. - 2011.

RFilter v1.0 - расчёт скорости фильтрации загрязнителей почвенного и водонос- ных горизонтов в условиях сельскохозяйственного производства / К.А. Селезнев, С.А. Плыгун // Свидетельство о государственной регистрации программы для ЭВМ №2011613400. 2011.

MFilter v1.0 - расчет массопереноса в почвенном и водоносных горизонтах в условиях сельскохозяйственного производства / К.А. Селезнев, С.А. Плыгун // Свидетельство о государственной регистрации программы для ЭВМ №2011613401. - 2011.

Filter Complex v1.0 - расчет массопереноса в почвенном и водоносных горизонтах в вертикальном и латеральном направлениях в условиях интенсивного сельскохозяйственного производства / К.А. Селезнев, Н.Н. Лысенко, С.А. Плыгун, В.Т. Лобков // Свидетельство о государственной регистрации программы для ЭВМ №2011614248. - 2011.

Экономическая оценка эффективности технологии возделывания зерновых культур v1.0 / В.T. Лобков, С.А. Плыгун, А.А. Полухин // Свидетельство о государственной регистрации программы для ЭВМ №2011614656. - 2011.

Оценка эффективности использования производственного потенциала в сельском хозяйстве v1.0 / А.А. Полухин, С.А. Плыгун, А.В. Алпатов, А.Н. Ставцев // Свидетельство о государственной регистрации программы для ЭВМ №2011614654. - 2011. 